一原著一

\title{
アゾカップリング反応を用いた一酸化二窒素の新規分析法
}

新田篤志，掛橋秀直，浅井龍太郎，和田美暁，中野史保子，松田駿太朗 志摩典明, 鎌田 徹, 西岡 裕, 三木昭宏, 片木宗弘

\author{
大阪府警察本部科学捜査研究所 \\ 干541-0053 大阪府大阪市中央区本町 1-3-18
}

\section{A new method for detection of nitrous oxide using azo coupling reaction}

\author{
Atsushi Nitta, Hidenao Kakehashi, Ryutaro Asai, Misato Wada, Shihoko Nakano, \\ Shuntaro Matsuta, Noriaki Shima, Tooru Kamata, Hiroshi Nishioka, \\ Akihiro Miki and Munehiro Katagi \\ Forensic Science Laboratory, Osaka Prefectural Police H.Q. \\ 1-3-18, Hommachi, Chuo-ku, Osaka 541-0053, Japan \\ (Received 15 May 2017; accepted 2 August 2017;
}

Published online 19 September 2017 in J-STAGE DOI: 10.3408/jafst.737)

This paper reports a new qualitative analytical approach, based on a color reaction for the detection of nitrous oxide $\left(\mathrm{N}_{2} \mathrm{O}\right)$, in order to solve problems of existing methods. The coloration was caused by the azo coupling of $\mathrm{N}_{2} \mathrm{O}$ with a Grignard reagent and 1-naphthol in the presence of $\mathrm{CuCl}_{2}$, which generated an orangecolored product 4-(phenylazo)-1-naphthol (4-PN) known as an azo dye compound. This color reaction provided both a simple color identification test and derivatization of $\mathrm{N}_{2} \mathrm{O}$ for its effective identification by gas chromatography/mass spectrometry (GC/MS) or liquid chromatography/tandem mass spectrometry (LC /MS/MS). This approach has several advantages such as: $\mathrm{N}_{2} \mathrm{O}$ was detectable by the color identification test quickly even when it was diluted with air, the derivative 4$\mathrm{PN}$ was detectable by GC/MS or LC/MS/MS using an ordinary separation column and detection limits were about $10 \%$ for the color identification test, $1 \%$ for GC/ MS, and $0.01 \%$ for LC/MS/MS. Thus, this method was found to be useful for both preliminary test and confirmation of $\mathrm{N}_{2} \mathrm{O}$ in street drug samples.

Key words: Nitrous oxide, Azo coupling, Color identification test, GC/MS, LC /MS/MS

* 本論文の内容は, 日本法科学技術学会第22回学術集会発表 (平成28年11月) に执いて奨励賞を受賞した. 


\section{緒 言}

近年，自転車タイヤ補充用ガスと称した「シバガ ス」と呼ばれる製品の急速な流通拡大が問題視され ている，その成分は一酸化二窒素 $\left(\mathrm{N}_{2} \mathrm{O}\right)$ という無 色かつほぼ無臭の気体であり，代表的な用途とし て, 病院での治療時に用いられる笑気麻酔 1,2$)$, ナ イトラス・オキサイド・システムに抢ける燃料の発 火促進剂 (3)，あるいはエスプーマという調理法に用 いられる，食材をムース状にするための食品添加 物4などが挙げられる。しかし，乱用者の目的は高 濃度の吸入によって得られる陶酔作用や多幸感2 の 享受であり，その結果引き起こされる健康被害や死 亡例が国内外で多数報告されている ${ }^{5-7)}$ 。こうした 背景を受け，同物質は平成 28 年 2 月から医薬品医療 機器法に規定の指定薬物として規制されており ${ }^{8)}$, 今後この法規制の遂行には各種捜査機関における $\mathrm{N}_{2} \mathrm{O}$ の分析・鑑定が必要不可欠となる.

$\mathrm{N}_{2} \mathrm{O}$ の分析法については, 多孔質層オープンチ ューブラーカラムを用いたガスクロマトグラフィー

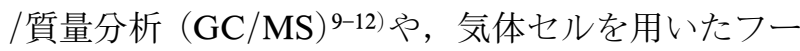
リ工変換赤外分光法 (FTIR) 12-16) が一般的に知られ ている.しかしながら，これらの分析法では，汎用 性に欠ける特別なカラムやセルを必要とする上, GC/MS では特徵的なフラグメントイオンに乏し く, FTIR では $\mathrm{N}_{2} \mathrm{O}$ が空気など他の気体と混合し ていた場合に赤外吸収スペクトルの干渉が起こるな ぞ，それぞれ欠点を抱えている。

$\mathrm{N}_{2} \mathrm{O}$ は非常に反応性の低い分子であり, 従来グ リニャール試薬に対して不活性であるとされていた が，2014年，Tskhovrebov らによって，テトラヒド ロフラン溶媒中の脂肪族グリニャール試薬は $\mathrm{N}_{2} \mathrm{O}$ と反応し，ヒドラゾンを生成することが報告され， その中間体としてジアゾ化合物を経由していること が示唆された ${ }^{17)}$ 。また2015年には，N-複素環式力 ルベンと $\mathrm{N}_{2} \mathrm{O}$ の反応により得られる付加生成物 に，ルイス酸触媒として塩化アルミニウムを加える ことで $\mathrm{N}-\mathrm{O}$ 結合の開裂が起こり，その結果生ずる ジアゾニウムイオンが，さらに芳香族化合物と求電 子置換反応を起こすことにより，最終的にアゾイミ ダゾリウム色素が生成するという反応が報告され

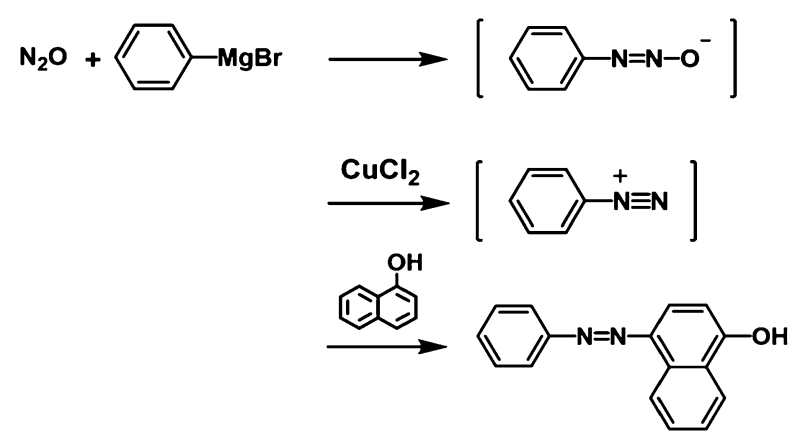

Fig. 1 Proposed mechanism for the formation of 4(phenylazo)-1-naphthol (4-PN) by the azo coupling reaction.

た ${ }^{18)}$.

我々は上記の報告を端緒に, $\mathrm{N}_{2} \mathrm{O}$ に特異的なア ゾカップリング誘導体化反応を考案した．想定され る反応機構は Fig. 1 に示す通りであり，この反応 機構に従い $\mathrm{N}_{2} \mathrm{O}$ が 4-(フェニルアゾ) -1-ナフトー ル（4-PN）へと誘導体化される４-PN は芳香族 アゾ染料の一種であり，当該溶液は，その液性や溶 媒により黄〜赤色を呈することが知られている ${ }^{19)}$. また，その化学構造から，GC/MS に抢ける検出に は特別なカラムを必要とせず，さらに液体クロマト グラフィー/タンデム質量分析 (LC/MS/MS) の適 用も可能であることが推定された。 そこで本研究で は，上記反応を利用することにより，呈色試験， $\mathrm{GC} / \mathrm{MS}$ および LC/MS/MS から構成される $\mathrm{N}_{2} \mathrm{O}$ の新規分析法の開発を目的とし，その条件検討抢よ び最適化を実施した。本法は，薬物取り締まりにお ける， $\mathrm{N}_{2} \mathrm{O}$ の迅速・簡便かつ信頼性の高い分析法 として有用であると考えられる。

\section{1. 実験材料}

\section{材料および方法}

\section{1. 試薬}

$\mathrm{N}_{2} \mathrm{O}$ 標準ガスはジーエルサイエンス製，1-ナフ トールは米山薬品工業製, 塩化銅 $\left(\mathrm{CuCl}_{2}\right)$ はシグ マアルドリッチ製，フェニルマグネシウムブロミド （16\%テトラヒドロフラン溶液，約 $1 \mathrm{M} ）$ は東京化 成工業製，ヘリウムはエア・リキード工業ガス製， シアン化ナトリウムは関東化学製，アジ化ナトリウ ムは林純薬工業製，亜硝酸イソアミル，LC/MS/ 
MS 用メタノールおよび酢酸アンモニウムは和光純 薬工業製を使用した。 また，アンモニアガスは $28 \%$ アンモニア水に水酸化カリウムを加えることにより 生成し，二酸化窒素は銅粒に濃硝酸を加えることに より生成した。

\subsection{4-PN 標準品の合成 20}

水冷したアニリンと希塩酸の混合溶液に亜硝酸ナ トリウム水溶液を加え, 塩化ベンゼンジアゾニウム を得た１ー・ナフトールを溶解させた水酸化ナトリウ ム水溶液にこれを加えることにより，4-PNを得 た。分取薄層クロマトグラフィーによる分離精製 後，核磁気共鳴法による同定を行い，適当な濃度に なるよう適宜溶媒で希釈して使用した.

\section{2. 分析方法}

\section{1. 呈色試験法}

あらかじめ 1-ナフトールおよび $\mathrm{CuCl}_{2}$ 粉末各 5 $\mathrm{mg}$ を封入したガラスバイアルに，検査気体を注入 し，次いで $1 \mathrm{M} フ ェ$ フマグネシウムブロミドを 注入した後, ガラスバイアルを 10 秒程度激しく撹拌 した。最後に $1 \mathrm{M}$ 塩酸を注入し, 再びバイアルを 軽く撹拌した後, 直ちに有機層の呈色を観察した。

なお，検査気体および各試薬の注入にはそれぞれ SGE Analytical Science 製のガスタイトシリンジを 使用し，ガラスバイアルの規格および各注入量につ いては下記の 2 つの条件で実施した。

\section{(条件 $\mathrm{A}$ )}

ガラスバイアル : ジーエルサイエンス製ミニナート バルブ付サーモフィッシャーサイエンティフィック 製 $22 \mathrm{ml}$ 容ガラスバイアル

検查気体 : 約 $15 \mathrm{ml}$

$1 \mathrm{M}$ フェニルマグネシウムブロミド : $1 \mathrm{ml}$

$1 \mathrm{M}$ 塩酸 : $1 \mathrm{ml}$

(条件 B)

ガラスバイアル : シグマアルドリッチ製セプタムキ ヤップ付 $2 \mathrm{ml}$ 容ガラスバイアル

検查気体 : 約 $1 \mathrm{ml}$

$1 \mathrm{M}$ フェニルマグネシウムブロミド : $0.5 \mathrm{ml}$

$1 \mathrm{M}$ 塩酸 : $0.5 \mathrm{ml}$

\section{2. 可視吸収スペクトル測定}

呈色試験後の有機層を分取し，ミリポア製ウルト ラフリーMC（フィルター孔径 $0.65 \mu \mathrm{m}$ ）を用いて
ろ過した後, テトラヒドロフランを用いて10倍に希 釈し，可視吸収スペクトルを測定した。

装置：島津製作所製 Prominence SPD-M20A

スリット幅 : $1.2 \mathrm{~nm}$

測定波長 : 400-780 nm

サンプリングタイム：0.24秒

光源 : 重水素抢よびタングステンランプ

\section{3. 質量分析}

\subsection{1. 前処理}

呈色試験後の有機層 $250 \mu \mathrm{l}$ を $2 \mathrm{ml}$ 容マイクロチ ューブに移し，へキサンおよび $0.1 \mathrm{M}$ 水酸化ナトリ ウム水溶液各 $250 \mu \mathrm{l}$ を加え, 擋拌後遠心分離し, 可 能な限り水層を分取した。この抽出操作を 2 回行 い，得られた水層を合わせ，そこに酢酸エチル250 $\mu \mathrm{l}$ および $1 \mathrm{M}$ 塩酸 $50 \mu \mathrm{l}$ を加え, 擋拌後遠心分離 し，有機層 $50 \mu \mathrm{l}$ を GC/MS 打よび LC/MS/MS 用 にそれぞれ分取した。得られた有機層について, 窒 素気流化で溶媒を留去し残渣を得た。

\subsubsection{GC/MS}

前処理によって得られた残渣に N-メチルーN-ト リメチルシリルトリフルオロアセトアミド

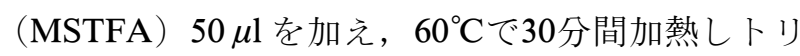
メチルシリル（TMS）誘導体化を行った．その後 ヘキサンを用いて適宜希釈し GC/MS の試料とした. 装置：島津製作所製 GCMS-QP2010 Ultra

カラム : アジレント・テクノロジー社製 DB-5MS $(30 \mathrm{~m} \times 0.32 \mathrm{~mm}$ i.d., 膜厚 $0.25 \mu \mathrm{m})$ カラム温度 : $80^{\circ} \mathrm{C}$ (1 分) $-20^{\circ} \mathrm{C} /$ 分 $-320^{\circ} \mathrm{C}$ (1 分) 気化室温度 : $250^{\circ} \mathrm{C}$ キャリアガス : $\mathrm{He}, 3.6 \mathrm{ml} /$ 分

注入量 : $1 \mu \mathrm{l}$, スプリット比 $(1: 5)$ イオン化法 : 電子イオン化 (EI) 法 イオン化エネルギー : $70 \mathrm{eV}$

イオン源温度 : $200^{\circ} \mathrm{C}$

インターフェース温度 : $250^{\circ} \mathrm{C}$

測定モード : スキャン $(m / z 40-600)$

\subsubsection{LC/MS/MS}

前処理によって得られた残渣に50\%メタノール50 $\mu \mathrm{l}$ を加え，適宜希釈し LC/MS/MS の試料とした。 装置 : 島津製作所製 Prominence UFLC およびサー モフィッシャーサイエンティフィック社製 LTQ 
$\mathrm{XL}$

カラム : 化学物質評価研究機構製 L-column2 ODS $(150 \mathrm{~mm} \times 1.5 \mathrm{~mm}$ i.d., 粒子径 $5 \mu \mathrm{m}$ )

カラム温度 : $40^{\circ} \mathrm{C}$

移動相：A； 5\%メタノール $10 \mathrm{mM}$ 酢酸アンモニウ ム，B；95\%メタノール10 mM 酢酸アンモニウム グラジエント条件：B 50\%（0分）一直線グラジエン 卜（0-7.5分）-B 100\%（7.5-15分）-B 50\%（1525分）

流速 : $0.1 \mathrm{ml} /$ 分

注入量 : $5 \mu \mathrm{l}$

イオン化法：エレクトロスプレーイオン化（ESI）

法（ポジティブ）

キャピラリー電圧 : $7 \mathrm{~V}$

キャピラリー温度 $: 275^{\circ} \mathrm{C}$

測定モード：フルスキャン $(m / z 100-1000)$ 打よ び $m / z$ 249をプリカーサーイオンとしたプロダクト

イオンスキャン $(m / z 55-260)$

ノーマライズドコリジョンエネルギー : $35 \%$

\section{結果および考察}

\section{1. 呈色試験}

材料および方法2.1. 項で示した条件 A に基づき実 施した呈色試験の結果を Fig. 2 に示す。なお検査 気体として, 陰性対照試料には空気を, 陽性対照試 料には $\mathrm{N}_{2} \mathrm{O}$ 標準ガスを注入した。希塩酸注入後の 有機層を観察したところ, 陰性では白〜淡褐色，陽 性では直ちに鮮やかな橙色の呈色を示した。この呈 色反応は，単一ガラスバイアル内に各試薬を注入す るだけの簡便な操作によって進行し，またその所要 時間も短いことから， $\mathrm{N}_{2} \mathrm{O}$ の検出法として利用す

(a)

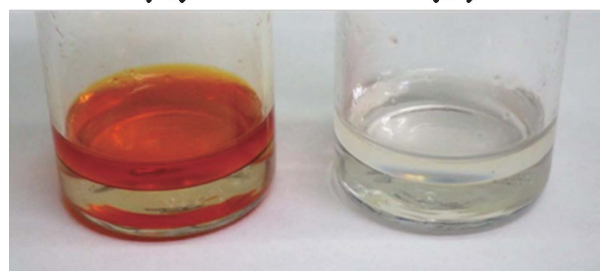

Fig. 2 Color reactions for $\mathrm{N}_{2} \mathrm{O}$ determination. (a) Positive $\left(\mathrm{N}_{2} \mathrm{O}\right)$ and (b) negative (air) controls.
るのに有効であると考えられた，以下では，本呈色 試験の確立に向けて実施した検討内容について記述 する。

\section{1. 呈色反応}

本反応により得られた陽性対照試料の有機層は, 4-PN 標準品をテトラヒドロフランに溶かしたもの と同様の呈色を示した。また，陰性対照試料の有機 層も併せて，材料抢よび方法2.2. 項で示した操作に 従いこれらの可視吸収スペクトルを測定し，比較を 行った。その結果, 陽性対照試料の吸収スペクトル は，陰性対照試料に比べて400-550 nmの波長域で の吸収が大きく，また， $460 \mathrm{~nm}$ および $510 \mathrm{~nm}$ 付近 に変曲点を有しており，標準品の吸収スペクトルと よく類似した（Fig. 3). 一方， $\mathrm{N}_{2} \mathrm{O}$ ，フェニルマグ
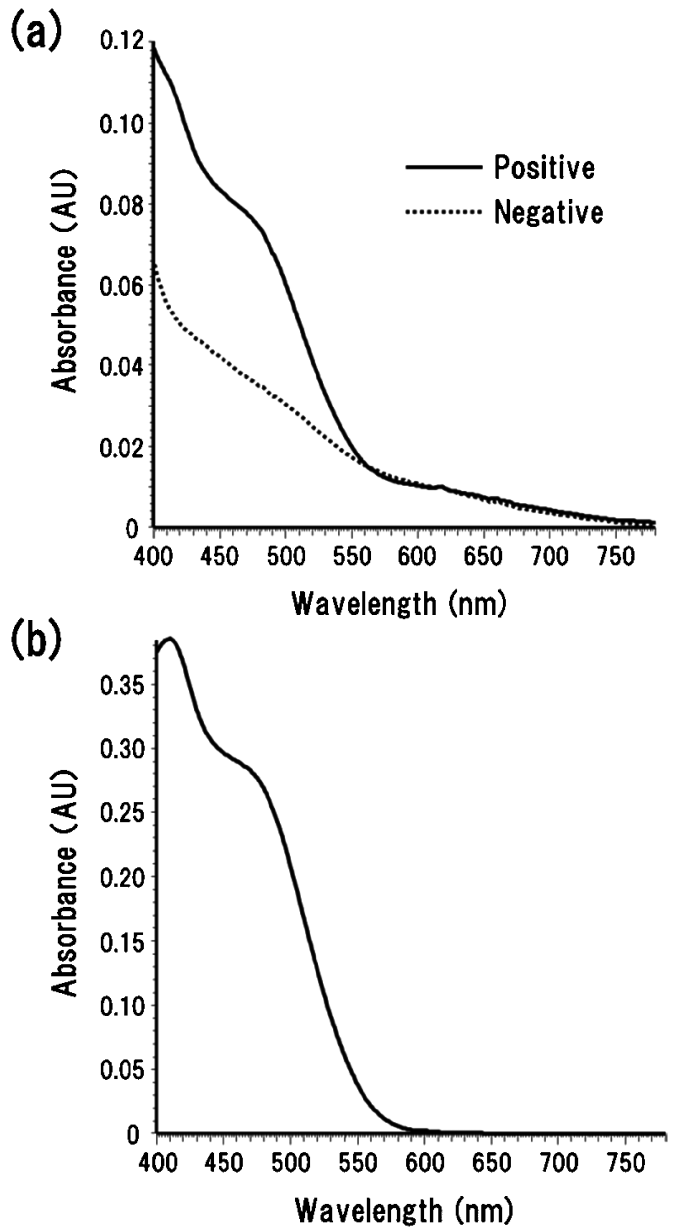

Fig. 3 Visible absorption spectra of (a) positive and negative controls, and (b) a tetrahydrofuran solution of 4-PN (AU: absorbance unit). 
ネシウムブロミド， 1-ナフトールあるいは $\mathrm{CuCl}_{2}$ のいずれか一つでも欠けた場合, 反応は進行せず, 試験溶液は上記呈色を示さなかった．続いて，1-ナ フトールおよび $\mathrm{CuCl}_{2}$ の用量について検討を行っ たところ，いずれも過剩量（約 $10 \mathrm{mg}$ 以上）の使用 により， $\mathrm{N}_{2} \mathrm{O}$ 非存在下でも有機層が顕著に褐色を 呈したため, 呈色判定の妨げとならないよう留意す る必要があった。また，フェニルマグネシウムブロ ミドは非常に反応性が高く，水や酸素と反応して失 活し，反応効率を大きく低下させてしまう要因とな るため, 試薬瓶の開封時間は必要最小限とし, 取 り扱うシリンジは錆びていないものを使用するなど の注意が必要であった。

\section{2. 試験操作}

本反応において，希塩酸注入前の擋拌時間が反応 効率に及ぼす影響を調べるため，擋拌時間を 0 秒か ら120秒の間で設定し，呈色の比較を行った。その 結果，擋拌なしでは十分に呈色しなかったものの, 10 秒程度激しく擋拌することによって鮮明な呈色が 示され，それ以上擋拌しても顕著な呈色の差は観察 されなかった，一方，反応終了後の試験溶液を室温 で放置し，呈色の経時変化を観察したところ， $\mathrm{N}_{2} \mathrm{O}$ の有無にかかわらず，数時間後には有機層が徐々に 褐色を帯びてしまう傾向が見られたため, 呈色の判 定は希塩酸注入後直ちに行うほうが望ましいと考え られた。

また，試験に用いるガラスバイアルの仕様・容量 について，材料抢よび方法2.1.項で示した条件 A お よび B を設定し，その結果を比較した。条件 A を 用いた場合，ミニナートバルブの使用による検査気 体および各試薬注入時の優れた操作性に加え, 条件 B に比べてより大きいスケールでの反応が可能であ り，質量分析を実施する上で十分な量の有機層が得 られた。一方，条件 B を用いた場合，より少量の $\mathrm{N}_{2} \mathrm{O}$ を用いて呈色試験を実施することが可能であ り, 条件 $\mathrm{A} の 1 / 10$ の注入量で概ね同程度の呈色を 示した (Fig. 4). また，この結果から，本呈色反 応効率は, 気体注入後のバイアル内における $\mathrm{N}_{2} \mathrm{O}$ の濃度に依存することが示唆された，以上より，本 呈色試験においては, 条件 $\mathrm{A}$ 打よび $\mathrm{B}$ の使い分け により，状況や目的に応じて検查を行うことが可能

\section{condition A}

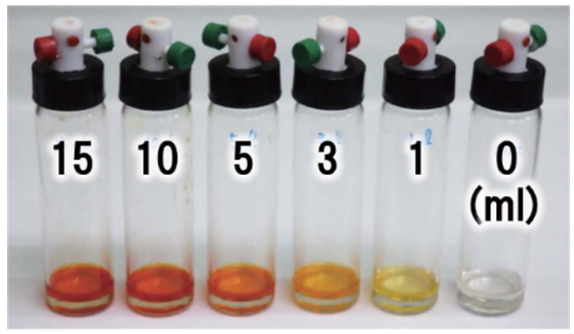

condition B

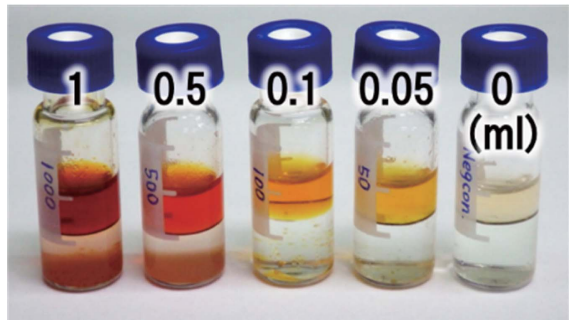

Fig. 4 Color reactions performed under conditions $\mathrm{A}$ and $\mathrm{B}$. The numbers represent injection volumes of $\mathrm{N}_{2} \mathrm{O}$.

であり，操作上，より扱い易いのは条件 A である が, 特に消費できる試料量が少ない状況では, 条件 Bの適用が有用であると考えられた。

\section{GC/MS}

呈色試験において，アゾカップリング誘導体化反 応による 4-PNの生成が示唆されたことから， GC/ MSを用いてその検出を試みた。材料および方法 2.2.2. 項で示した操作に従い GC/MS を実施し, 陽 性対照試料から得られたマスクロマトグラムおよび EIマススペクトルをFig. 5 に示す. クロマトグラ ム中11.4分付近にピーク A が検出され, そのマス スペクトルには, 分子イオン $\left(\mathbf{M}^{+\cdot}\right)$ である $m / z$

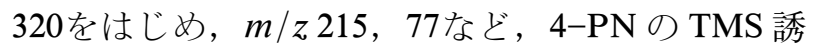
導体の構造に特徵的なピークが観測された。 また， 同様に実施した 4-PN 標準品の分析結果と比較した ところ, 保持時間およびマススペクトルがよく一致 した（Fig. 5).なお，4-PNは未変化体としても検 出可能であるが，TMS 誘導体化をすることによ り, その検出感度は10倍程度向上した. さらに, 材 料および方法2.2.1. 項で示した前処理における4PNの回収率を算出したところ, 約 $80 \%$ と良好な結 果が得られた。 

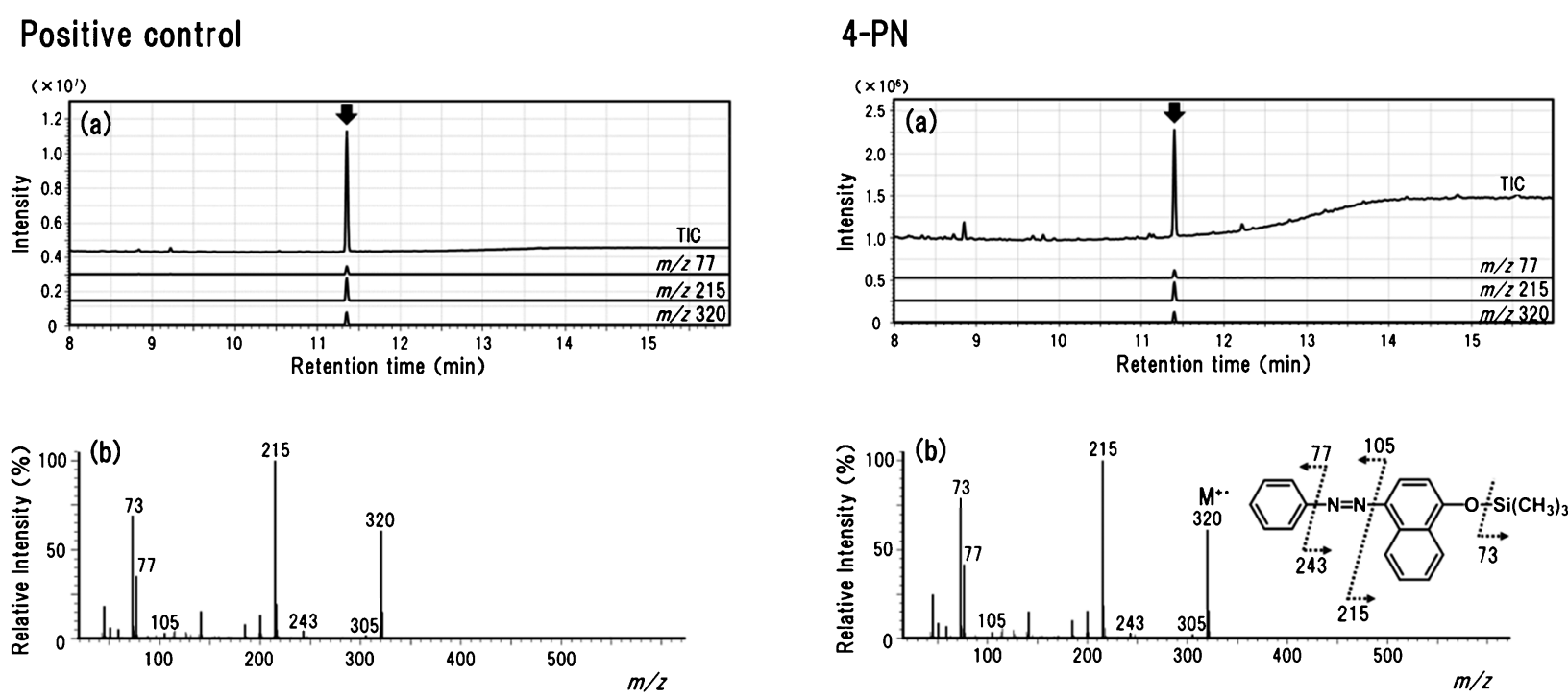

Fig. 5 (a) Total ion current chromatograms (TICs) and extracted ion chromatograms (EICs), and (b) electron ionization mass spectra of the marked peaks obtained from a positive control and a synthesized standard of 4-PN by gas chromatography/mass spectrometry.

Positive control
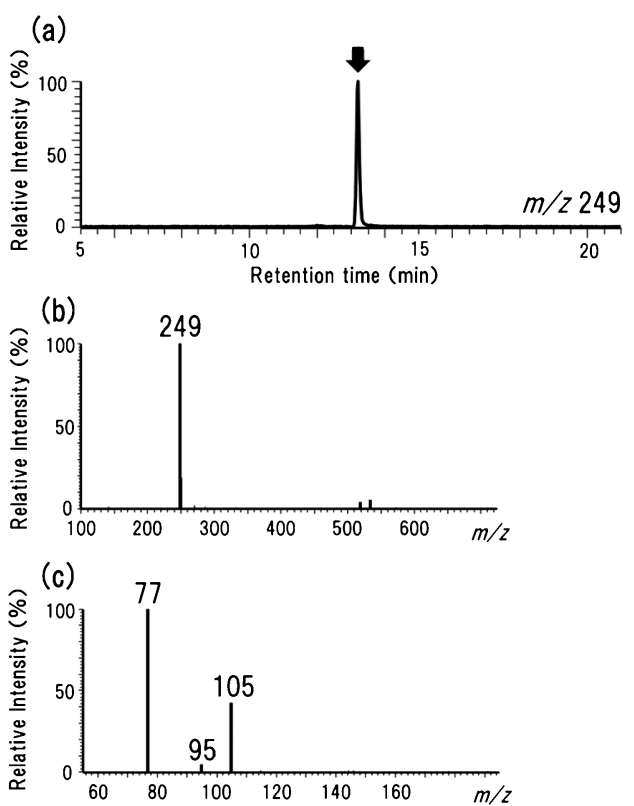

4-PN
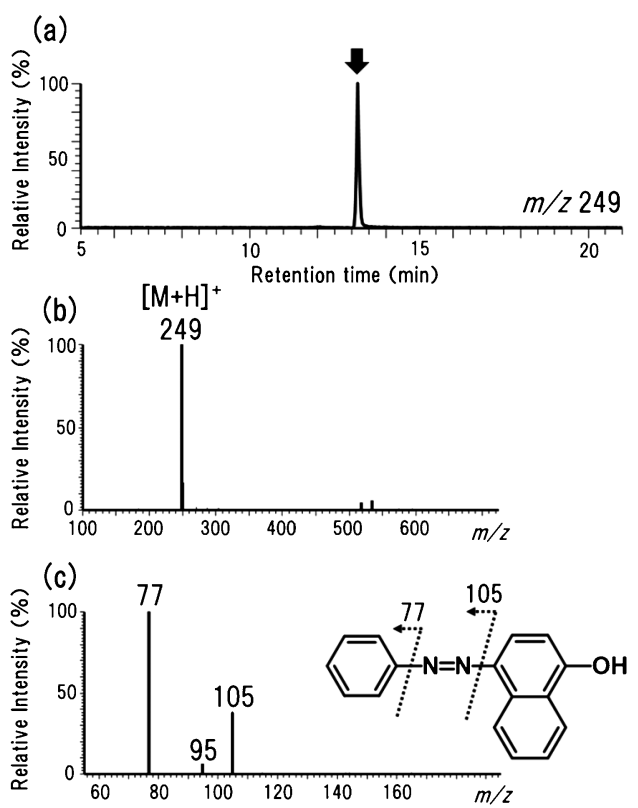

Fig. 6 (a) EICs, (b) electrospray ionization mass spectra of the marked peaks and (c) product ion spectra of $\mathrm{m} / \mathrm{z} 249$ obtained from a positive control and a synthesized standard of 4-PN by liquid chromatography/ tandem mass spectrometry.

\section{LC/MS/MS}

生成した 4-PN について, LC/MS/MS を用いた 検出を試みた。材料抢よび方法2.2.3. 項で示した操
作に従い LC/MS/MS を実施し，陽性対照試料から 得られたマスクロマトグラムおよびマススペクトル をFig. 6 に示す。クロマトグラム中13.2分付近に 
ピーク B が検出され，その ESI スペクトルには， 4-PNのプロトン化分子 $\left([\mathrm{M}+\mathrm{H}]^{+}\right)$に相当する $m / z 249$ のイオンが観測された。さらに， $m / z 249$ のイオンをプリカーサーとしてプロダクトイオンス キャンを行い，得られたプロダクトイオンスペクト ルには， $m / z 105,77$ な゙， 4-PN の構造に特徵的 なイオンが観測された。また, GC/MS 同様，標準 品の分析結果との比較を行い，保持時間およびマス スペクトルの一致を確認した (Fig. 6).

\section{4. $\mathbf{N}_{2} \mathbf{O}$ の検出限界}

呈色試験， $\mathrm{GC} / \mathrm{MS} ， \mathrm{LC} / \mathrm{MS} / \mathrm{MS}$ を用いた 4-PN の検出がそれぞれ可能であったことから，次に $\mathrm{N}_{2} \mathrm{O}$ を空気で希釈したものについて上記分析法を 実施し, 本法に打ける注入気体中の $\mathrm{N}_{2} \mathrm{O}$ 濃度の検 出限界を算出した. 材料および方法2.1. 項で示した 条件 B に従い得られた呈色試験の結果を Fig. 7 に 示す. $\mathrm{N}_{2} \mathrm{O}$ 濃度の減少に伴い呈色が淡くなる傾向 が見られ，陰性対照試料（0\%）と比較したところ， 概ね $10 \%$ の濃度まで呈色による判定が可能であっ た. 続いて呈色試験後の有機層を分取し，材料およ び方法2.2. 項で示した方法に従い質量分析を実施し たところ，GC/MS では 1\%，LC/MS/MS では0.01 \%まで4-PN の検出が可能であった． $\mathrm{N}_{2} \mathrm{O}$ は最小 肺胞内濃度が高く2), 歯科臨床診療における意識下 鎮静法には平均的に $40 \%$ 濃度の $\mathrm{N}_{2} \mathrm{O}$ が必要であ る21)ことから，乱用者の間で流通している製品中の $\mathrm{N}_{2} \mathrm{O}$ 濃度は, 本法を用いて十分に検出可能な範囲 であると想定された。なお今回の検討は条件 B を 用いて行ったが，この呈色反応の効率はバイアル内 の $\mathrm{N}_{2} \mathrm{O}$ 濃度に依存すると考えられるため, 条件 $\mathrm{A}$ を用いた場合でも同様の結果が得られると推定され

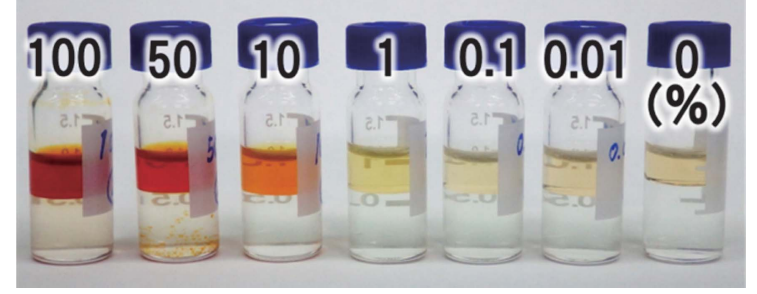

Fig. 7 Detection sensitivity of $\mathrm{N}_{2} \mathrm{O}$ in the color reaction. The numbers represent concentrations of $\mathrm{N}_{2} \mathrm{O}$.
た。

\section{5. $\mathbf{N}_{2} \mathbf{O}$ の特異性}

本誘導体化反応における $\mathrm{N}_{2} \mathrm{O}$ の特異性を確認す るため，主に揮発性乱用化合物や含窒素化合物を対 象とした $\mathrm{N}_{2} \mathrm{O}$ 以外の物質, すなわち常温で気体で あるアンモニア, ヘリウム, 二酸化窒素, また液体 や固体である亜硝酸イソアミル，トルエン，メタ ノール, 酢酸エチル, シアン化ナトリウム, アジ化 ナトリウムについて, 本分析法を適用し，その結果 を比較した. 材料抢よび方法2.1. 項で示した条件 A に基づき, 得られた呈色試験の結果を Fig. 8 に示 す。（ただし液体抢よび固体については気体注入量 と等モル量を分析に供し, トルエン, メタノールお よび酢酸エチルについては混合物として同一バイア ル内で検查を実施した.）いずれの物質も $\mathrm{N}_{2} \mathrm{O}$ と同 様の挙動は示さなかったものの, 二酸化窒素抢よび 亜硝酸イソアミルについては, 希塩酸の注入により 若干類似した呈色を示したため注意が必要であっ た。ただし二酸化窒素については, 気体自体が赤褐 色を有していることや，希塩酸注入前の時点でバイ アル内の溶液が黒褐色を示すことから $\mathrm{N}_{2} \mathrm{O}$ との識 別が可能であった．また亜硝酸イソアミルについて は, 常温で果実臭を帯びた液体であり, 同じく希塩
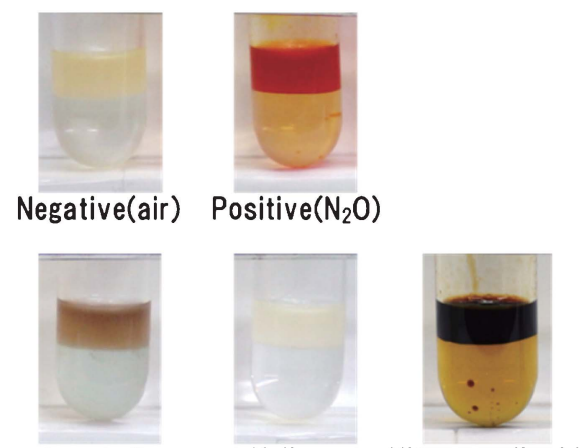

Ammonia

Helium

Nitrogen dioxide
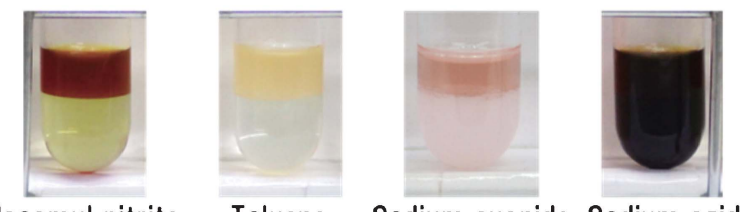

Isoamyl nitrite

Toluene

Sodium cyanide Sodium azide Ethyl acetate

Fig. 8 Specificity of the azo coupling reaction for $\mathrm{N}_{2} \mathrm{O}$. 
酸注入前の時点で溶液が暗赤褐色を示すことから識 別が可能であった。

さらに，呈色試験後の有機層をそれぞれ分取し， 材料抢よび方法2.2.2. 項で示した操作に従い GC/ MS を実施したところ，上記試料のいずれからも 4-PN は検出されず, 本反応における $\mathrm{N}_{2} \mathrm{O}$ の特異 性が確認された。

\section{結 語}

本研究は, $\mathrm{N}_{2} \mathrm{O}$ に特異的なアゾカップリング誘 導体化反応を考案し，その新規分析法の開発を行っ たものである。本法は，混合気体が $\mathrm{N}_{2} \mathrm{O}$ のスペク トルに干渉するといった, 従来法で起こり得る弊害 がなく，これまでにない簡便かつ迅速な呈色試験法 や，汎用カラムを用いた GC/MS および LC / MS / MS による誘導体の検出が可能であることから，よ り扱い易く信頼性の高い定性分析法として期待され る. $\mathrm{N}_{2} \mathrm{O}$ の検出限界は, 呈色試験, $\mathrm{GC} / \mathrm{MS}, \mathrm{LC} /$ MS/MS でそれぞれ約 $10 \% ， 1 \% ， 0.01 \%$ であり， 乱用者から押収された資料を分析対象として想定し た場合，十分に適用可能な水準を有していると考え られた。以上より，本法は研究室における新たな $\mathrm{N}_{2} \mathrm{O}$ の分析法としてはもちろん, 資料大量押収時 には，呈色試験を生かしたスクリーニング検査とし ての運用も見込まれる. また今後, 反応試薬や触 媒, 検查使用器具などについてさらなる検討を進め ることにより, 検出感度の向上や, 現場検査法とし て活躍することも期待される.

\section{文献}

1）萬家俊博, 全身麻酔に抢ける亜酸化窒素（笑 気）の有用性. 日本臨床麻酔学会誌，26，665670, 2006.

2) American Association for Clinical Chemistry, Nitrous Oxide, available from [https://www. aacc.org / community / divisions / tdm-andtoxicology / toxin-library / nitrous-oxide ] , accessed Feb 7, 2017.

3) 特許 US7451751 B2, Nitrous-oxide system.

4）東邦アセチレン株式会社，エスプーマでレシ ピが変わる，available from [http://www． espuma-ta.jp/], accessed Feb 3, 2017.

5) Henry R. J., Assessing environmental health concerns associate with nitrous oxide. J. Am. Dent. Assoc., 123, 41-47, 1992.

6) Gillman M. A., Nitrous oxide abuse in perspective. Clin. Neuropharmacol., 15, 297-306, 1992.

7）英国放送協会，How dangerous is laughing gas ?, available from [http://www.bbc.com/ news/magazine-33691783], accessed Feb 7, 2017.

8）厚生労働省，一酸化二窒素（別名：亜酸化窒 素）を新たに指定薬物に指定，available from [http://www.mhlw.go.jp/stf/houdou/0000112797. html], accessed Feb 3, 2017.

9）花井義道，加藤龍夫，荒井隆則，大気中亜酸 化窒素の GC-MS による測定. 横浜国立大学環 境科学研究センター紀要, 5, 35-39, 1979.

10) Isobe K., Koba K., Ueda S., Senoo K., Harayama S. and Suwa Y., A simple and rapid GC/MS method for the simultaneous determination of gaseous metabolites. J. Microbiol. Methods, 84, 46-51, 2011.

11) Giuliani N., Beyer J., Augsburger M. and Varlet V., Validation of an analytical method for nitrous oxide $\left(\mathrm{N}_{2} \mathrm{O}\right)$ laughing gas by headspace gas chromatography coupled to mass spectrometry (HS-GC-MS): Forensic application to a lethal intoxication. J. Chromatogr. B Analyt. Technol. Biomed. Life Sci., 983-984, 90-93, 2015.

12）飯田英己，黒澤英俊，宮元礼生奈，滝口貴 広, 伊澤秀二郎, 工藤雅孝, 日本法中毒学会第 35年会講演要旨集. $63,2016$.

13) Rapson T. D. and Dacres H., Analytical techniques for measuring nitrous oxide. Trends Analyt. Chem., 54, 65-74, 2014.

14) Zhao Y., Wexler A. S., Hase F., Pan Y. and Mitloehner F. M., Detecting Nitrous Oxide in Complex Mixtures Using FTIR Spectroscopy: Silage Gas. J. Environ. Prot., 7, 1719-1729, 2016.

15) Esler M. B., Griffith D. W. T., Turatti F., Wilson S. R., Rahn T. and Zhang $\mathrm{H}$., $\mathrm{N}_{2} \mathrm{O}$ con- 
centration and flux measurements and complete isotopic analysis by FTIR spectroscopy. Chemosphere Glob. Change Sci., 2, 445-454, 2000.

16) Sanchez A., Eddings E. and Mondragon F., Fourier Transform Infrared (FTIR) Online Monitoring of $\mathrm{NO}, \mathrm{N}_{2} \mathrm{O}$, and $\mathrm{CO}_{2}$ during OxygenEnriched Combustion of Carbonaceous Materials. Energy Fuels, 24, 4849-4853, 2010.

17) Tskhovrebov A. G., Solari E., Scopelliti R. and Severin K., Reactions of Grignard Reagents with Nitrous Oxide. Organometallics, 33, 2405-2408, 2014.
18) Tskhovrebov A. G., Naested L. C. E., Solari E., Scopelliti R. and Severin K., Synthesis of Azoimidazolium Dyes with Nitrous Oxide. Angew. Chem. Int. Ed., 54, 1289-1292, 2015.

19) Griffiths J., Prediction of Colour Change in Dye Equilibria I-Azo and Hydrazone Tautomers and Anions of 4-Phenylazo-1-naphthols. Color. Technol., 88, 106-109, 1972.

20) Merino E., Synthesis of azobenzenes: the coloured pieces of molecular materials. Chem. Soc. Rev., 40, 3835-3853, 2011.

21) Jastak J. T. and Donaldson D., Nitrous Oxide. Anesth. Prog., 38, 142-153, 1991. 